Article

\title{
Tree Ring-Based Estimation of Landslide Areal Reactivation as a Fundament of Magnitude-Frequency Assessment
}

\author{
Karel Šilhán \\ Department of Biology, University of Hradec Králové, Rokitanského 62, 50003 Hradec Králové, Czech Republic; \\ karel.silhan@uhk.cz; Tel.: +42-049-333-2755
}

Received: 4 March 2020; Accepted: 2 April 2020; Published: 3 April 2020

check for updates

\begin{abstract}
Magnitude-frequency (M-F) relationships represent important information on slope deformation and are used in hazard assessment or as supporting data for urban planning. Various approaches have been used to extract such relationships in the past, but most of these methods drove at the problem of exact events' frequency determination. Dendrogeomorphic (tree ring-based) approaches are actually thought to be the most precise method of dating past mass movement events that occurred within the last several centuries. Together with information on the spatial positions of the analysed trees, they represent a potentially very valuable tool for reconstructing $\mathrm{M}-\mathrm{F}$ relationships, although their use for this purpose has been very rare in the past. In this study, M-F relationships are reconstructed using dendrogeomorphic methods for three landslides of different types (a translational slide, a flow-like slide, and a rotational slide) occurring in different geological materials (thick-bedded flysch, limestone marls, and volcanic breccia). In total, 572 disturbed trees were analysed, and chronologies of mass movement events were built. Landslide magnitudes were expressed in three ways: (i) the value of the standard $I_{t}$ index; (ii) the area, as determined using homogenous morphological units; and (iii) the area, as determined using tree buffers. The power-law nature of M-F relationships was confirmed for all the landslides that were studied and using all the approaches that were applied. All of the combinations of results yielded high correlation values; nevertheless, differences were noted. The advantages and limitations of each approach used to reconstruct $\mathrm{M}-\mathrm{F}$ relationships are also discussed.
\end{abstract}

Keywords: landslide; reactivation area; dendrogeomorphology; frequency

\section{Introduction}

Many questions connected with landslide hazard assessment have been solved (the movement mechanism, relative stability, triggers, etc.). The determination of magnitude-frequency (M-F) relationships (e.g., high magnitude-low frequency events vs. low magnitude-high frequency events) is one of the most important factors and is a very common subject of investigation. An understanding of the $\mathrm{M}-\mathrm{F}$ relationships of landslides provides an important basis for recommendations in hazard assessment, urban planning or protective measures [1]. M-F relationships have been reconstructed and analysed by many authors for various natural hazards, including rockfalls [2,3], debris flows [4-7], floods [8,9], and landslides [10-12]. The magnitude of mass movement events can be expressed as the area of the reactivated part of a landslide [13-16], or the volume of the moving mass [17]. Field inventories of signs of landslides, approaches based on remote sensing techniques, and modelling of landslide volumes are methods that are often applied for this purpose. On the other hand, the application of absolute dating methods seems to be the most exact approach for the determination of landslide frequency [18]. At the same time, this aspect of M-F relationships is at least as difficult to determine 
as event magnitudes. The timings of very recent mass movement events can be determined from archives or eyewitness observations [19]. However, these data are often incomplete, particularly in remote, unpopulated areas. Older mass movement events can be dated using a wide variety of numerical dating methods (14C, cosmic ray exposure, luminescence methods, or tephrochronology [20]). The most important problem associated with these methods is their limited accuracy (due to the probabilistic character of results) and the minimum event age that can be analysed (up to several hundreds or thousands of years). Moreover, only high-magnitude mass movement events are generally detectable by these methods. Therefore, potential problems in landslide frequency determination occur for the period covering the last several centuries. This gap can be bridged by tree ring-based (dendrogeomorphic) methods [21]. Approaches based on the identification and dating of growth disturbances in tree ring series induced by landslide movements are actually thought to be the most accurate for dating mass reactivation events that have occurred during the last several centuries in areas of temperate forest [22,23]. Dendrogeomorphic methods are frequently used for analyses of debris flows [24-26], snow avalanches [27,28], rockfalls [29-31], floods [32-34], and earth slides [35-37]. As dendrogeomorphic methods provide information on the temporal occurrence of mass movement events with seasonal precision and on the spatial distribution of the affected trees, M-F relationships can, theoretically, be reconstructed in the case of landslide movements [38]. Unfortunately, very few dendrogeomorphic studies have addressed this research question. In [39], the authors reconstructed M-F relationships for 62 debris flow events that have occurred since 1863 . The exact positions of trees related to individual accumulation forms of debris flows and the calculated accumulation volumes yielded M-F relationships that could be compared with hydrometeorological records. Similarly, [40] used tree ring-based methods for the determination of debris flow frequency for use in analysing $\mathrm{M}-\mathrm{F}$ relationships. Up to now, the most elaborate approach used in the determination of M-F relationships using tree ring-based methods was presented by [41]. Considering the various types of geomorphic processes (rockfalls, debris flows, and earth slides) and their differing natures, they applied specific approaches for the determination of the affected areas based on the position of analysed trees. They verified the power-law M-F relationship in the case of landslides, but according to the authors, their results are only preliminary [41] due to the limited number of trees analysed (49 individuals). The chronological aspects of dendrogeomorphic methods in the determination of M-F relationships are well developed [23,36,42-44]. The potential uncertainty remains in the case of the quantification of affected areas. In [41], the authors used basic morphological units of landslides, in combination with the positions of affected trees, to quantify the area affected by slide movements in individual event years. Unfortunately, this approach has limited applicability in some types of landslides with smoothed homogenous morphology (i.e., without morphologically well-defined zones: individual blocks, tension cracks, pressure folds, etc.).

From the foregoing discussion, it is obvious that dendrogeomorphic methods potentially represent a usable tool for determining M-F relationships for landslides, but some aspects have yet to be addressed. Thus, the aim of this study is (i) to introduce various approaches for determining magnitudes (in areal expression) using tree ring data for different types of landslides, and (ii) to present dendrogeomorphic methods as a highly valuable tool for obtaining data for the determination of $\mathrm{M}-\mathrm{F}$ relationships in landslide analysis.

\section{Study Area}

Three landslides with various movement mechanisms that have occurred in various morphological, morphometric and geological conditions were selected for this analysis. This approach enables detailed testing of various dendrogeomorphic procedures on different types of landslides. Typical representatives of three different types of landslides were selected (Figure 1A). The Mazák landslide represents a translational landslide [37,45]; the Lipová stráň landslide represents a rotational landslide [46]; and the L'ubietová landslide represents a flow-like landslide [47,48]. 

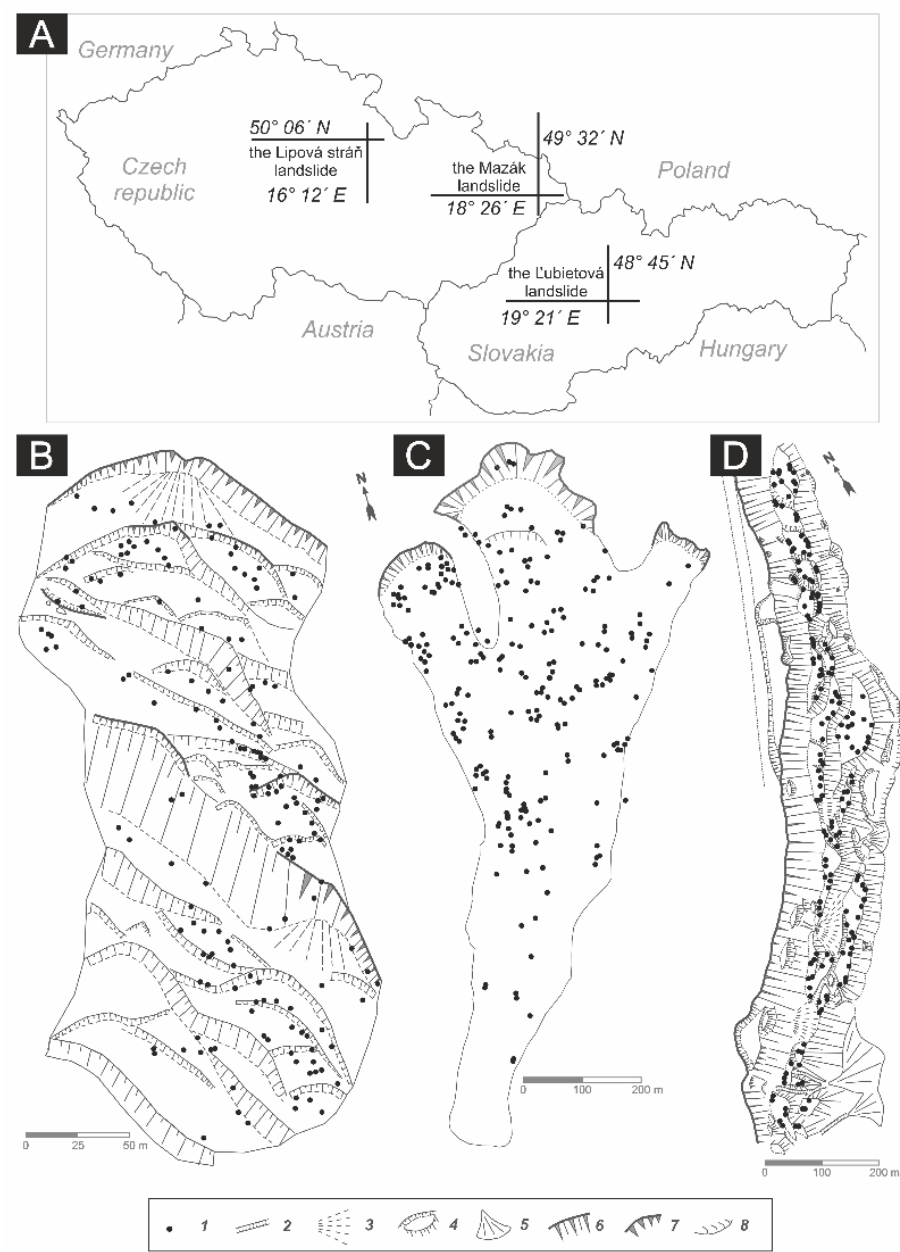

Figure 1. The locations of the studied localities in the Czech Republic and Slovakia (A), as well as geomorphic maps of the Mazák landslide (B), the L'ubietová landslide $(\mathbf{C})$, and the Lipová strán̆ landslide (D) (1-sampled trees; 2-gully; 3-talus; 4-partial landslide block; 5-alluvial fan; 6-main scarp; 7-rock exposure; 8 -accumulation lobe).

The Mazák landslide $\left(49^{\circ} 32^{\prime} \mathrm{N}, 18^{\circ} 26^{\prime} \mathrm{E}\right.$; length $400 \mathrm{~m}$; maximal width $180 \mathrm{~m}$; vertical range $200 \mathrm{~m}$ ) is one of the most active landslides in the Czech part of the Outer Western Carpathians. It is located in the vicinity of Lysá hora Mt. (the highest peak of the Moravskoslezské Beskydy Mts. with mean annual precipitation totals of $1390 \mathrm{~mm}$ ). The slope affected by the landslide is composed of thick-bedded flysch that is dominated by sandstones interbedded with shales. The rock dip conforms to the slope. Disrupted, cracked sandstone slabs with thicknesses up to $5 \mathrm{~m}$ move on the weak shale layers. Secondary scarps separate individual sliding slabs. The translational character of the slide is dominated by irregular topography, hummocky relief, rocky scarps, and tension cracks (Figure 1B). The Mazák landslide is predominantly covered by Norway spruce (Picea abies (L.) Karst.).

The Lipová stráň landslide $\left(50^{\circ} 06^{\prime} \mathrm{N}, 16^{\circ} 12^{\prime} \mathrm{E}\right.$; width $1200 \mathrm{~m}$; vertical range $\left.75 \mathrm{~m}\right)$ is a rotational, frontal slide developed in subhorizontal layers of limestone marls [49]. It occurs in the foreland of the Orlické hory Mts. (with a mean annual precipitation of 550-700 $\mathrm{mm}$ ) on a slope that was undercut by the Divoká Orlice river in the past. The landslide is composed of individual more or less rotated marl blocks occurring on several levels above the landslide base. The landslide morphology is dominated by inclined block surfaces separated by steep secondary scarps (Figure 1D). Several tree species dominate the forest cover of the Lipová stráň landslide, specifically littleleaf linden (Tilia cordata Mill.), European beech (Fagus sylvatica L.), Norway spruce (P. abies), and European larch (Larix decidua Mill.). 
The L'ubietová landslide $\left(48^{\circ} 45^{\prime} \mathrm{N}, 19^{\circ} 21^{\prime} \mathrm{E}\right.$; area $0.3 \mathrm{~km}{ }^{2}$; length $1200 \mathrm{~m}$; vertical range $\left.150 \mathrm{~m}\right)$ is one of the best-known landslides of the Central Slovakia Neogene Volcanic Field (with a mean annual precipitation of $750-850 \mathrm{~mm}$ ), due in particular to its catastrophic reactivation in 1977 . This landslide can be characterized as being a flow-like slide. The upper part of the affected slope is made up of rigid blocks of volcanic breccia to conglomerates that grade into clay-rich colluvial slope deposits [50]. The earthflow consists of three individual flows in the source zone that flow together into one large flow in the upper third of the affected area. The landslide surface has a hummocky character with typical flow-like morphology (Figure 1C). The landslide is primarily covered by Scots pines (Pinus sylvestris L.).

\section{Materials and Methods}

The tree ring data used in this study for the reconstruction of M-F relationships have previously been partly (chronological aspects) used in the studies of [37], who investigated the Mazák landslide; [46], who investigated the Lipová strán̆ landslide; and [48], who investigated the L'ubietová landslide. The data in the studies mentioned above were used for classical chronological reconstruction of past mass movement as a basis for the analysis of triggers. The use of tree ring data from all three localities for the reconstruction of areal extension of reactivation events and $\mathrm{M}-\mathrm{F}$ relationships is new and represents a different approach compared to those applied in the previously mentioned studies.

All trees that exhibited signs of past landslide activity (external disturbances, such as tilted stems or damaged root systems) were selected for sampling. First, the positions of all trees were recorded using GPS or a laser rangefinder and a compass in cases where the GPS signal was weak. The selected trees were sampled using a Pressler increment borer (diameter $0.5 \mathrm{~cm}$; maximum length $40 \mathrm{~cm}$ ) at the height corresponding to maximum stem bending. Four increment cores were extracted from each tree. One core was extracted from the direction of stem inclination, another one was extracted from the opposite side of the stem, and two cores were extracted at right angles to the previously mentioned cores. In total, 2288 increment cores were collected from 572 trees. One hundred and seventy-six individuals of $P$. abies were sampled on the Mazák landslide, 219 individuals of $P$. sylvestris were sampled on the L'ubietová landslide, and 177 trees (93 P. abies; 84 F. sylvatica) were sampled on the Lipová stráň landslide. Moreover, 30 undisturbed trees (of the same species as the disturbed trees) growing close to the analysed locality (but outside the area affected by the landslide movements) were always sampled for reference chronology reconstruction. All samples were processed following standard procedures [51]; the steps included drying, gluing into woody supports, sanding, ring counting, and measuring of tree ring widths (precision $0.01 \mathrm{~mm}$ ) using a TimeTable dendrochronological device and PAST4 software [52] under a binocular microscope. Increment curves from disturbed trees were cross-dated against the reference chronology to identify and correct for false or missing tree rings. The dating of mass movement events was based on the identification of growth disturbances (GD) in tree ring series. The basic identified growth disturbances were reaction (compression) wood in the case of coniferous trees as a growth response to stem tilting [53], abrupt growth suppression as a response to damage of trees' root systems [54], and eccentric growth as a growth response to stem inclination [55]. Growth disturbances were considered to be landslide-induced only in cases where they were not simultaneously observed in the reference chronology. The landslide chronology was expressed by the standard event-response $\left(I_{t}\right)$ index according to [56]:

$$
I t=\sum R_{t} / \sum N_{t} \times 100 \%
$$

where $R_{t}$ is the number of trees with an external signal (growth disturbance) in year $t$, and $N_{t}$ is the number of all sampled trees that were alive in year $t$. The minimum $I_{t}$ value that was considered as representing a mass movement event was determined to be $5 \%$ (based on the total number of sampled trees [23]). The frequency of mass movement events has temporal meaning in this study (i.e. frequency of events in a time series). The expression as a count of events or cases in the datasets is another 
possibility [15], but this is not the case here. The frequency of mass movement events $(f)$ was expressed as the number of events per year [57]. It was calculated as the ratio of the number of years covered by a sufficient number of living trees and the number of mass movement events reaching the minimum $I_{t}$ value.

The magnitude of mass movement events (in areal form) was calculated in three ways, and the results were compared to discover the most suitable method for the various types of landslides. The simplest way to express the magnitude of mass movement events is the value of the $I_{t}$ index. The $I_{t}$ values have been used several times as a basis for the analysis of relationships with potential triggers [36,37]. The second method for expressing landslide magnitudes was adapted from [41] and slightly modified. The landslide areas were divided according to their morphology into several homogenous morphological units (e.g., individual sliding blocks, isolated levees, scarps, etc.). Moreover, the proportion of landslide area afforestation was determined. The magnitude of an event was expressed as the percentage of area of all units that contain at least one tree with a landslide signal in a given year from the total area afforested by landslide. This approach could not be applied to the L'ubietová landslide due to the smoothed flow-like character of its surface, which made it impossible to delineate individual morphological units. The last approach used to represent landslide magnitude was based on the quantification of the cumulative area around all trees that displayed landslide signals in a given year. The quantified area around the position of each tree was defined as a regular buffer with a mean diameter of $5 \mathrm{~m}$. This distance was chosen as an approximate mean extension of the root plate of the trees, and it implies that the calculated buffer area around each tree should cover the minimum area affected by landslide movement that is recorded in the tree ring series. Trees with shorter distances than $10 \mathrm{~m}$ (twice the buffer diameter) among each other necessarily have buffer areas that overlap. In such cases, the buffer areas do not add up. Instead, the total area contained within the buffer borders is calculated. The landslide magnitude was expressed as a percentage of buffer area from the afforested area of landslide. The relative character (expressed in \%) of the second and third approach is important for the possibility of comparison among all approaches. The calculation of landslide magnitude following the second and third approaches was carried out using ArcGIS 10.1 software [58].

Magnitude-frequency relationships are generally known to obey power laws. According to [41], it is possible to express the slopes of $\mathrm{M}-\mathrm{F}$ relationships using the regression:

$$
F=A^{*} M^{-b}
$$

where $F$ is the cumulative frequency of mass movement events (events.yr ${ }^{-1}$ ), $M$ is the landslide magnitude (expressed as $I_{t}$, or the area based on morphological units, or area based on the tree buffers), and $A$ and $b$ are constants. $b$ is particularly important as its value can reflect specific conditions influencing the landslide behavior (e.g., geology) [2].

\section{Results}

\subsection{Number of Sampled Trees, Dated Growth Disturbances and Reconstructed Mass Movement Events}

The oldest trees sampled were found on the Lipová stráň landslide (mean age 95.9 years; stdev 29.5 years), whereas the youngest trees sampled grew on the L'ubietová landslide (mean age 23.1 years; stdev 4.4 years). The mean age of sampled trees on the Mazák landslide was 89.3 years (stdev 7.6 years). The largest number of disturbed trees grew on the Mazák landslide (3.2 GD per tree on average; 560 GD in total), whereas only 1.7 GD per tree on average (305 GD in total) were identified in trees on the Lipová stráň landslide. The trees on the L'ubietová landslide expressed 2.2 GD per tree on average (485 GD in total). The longest chronology was reconstructed for the Mazák landslide (100 years; 1912-2011) (Figure 2), and the shortest chronology was obtained for the L'ubietová landslide (33 years; 1983-2015). The length of the reconstructed chronology for the Lipová strán̆ landslide was 66 years (1949-2014). 


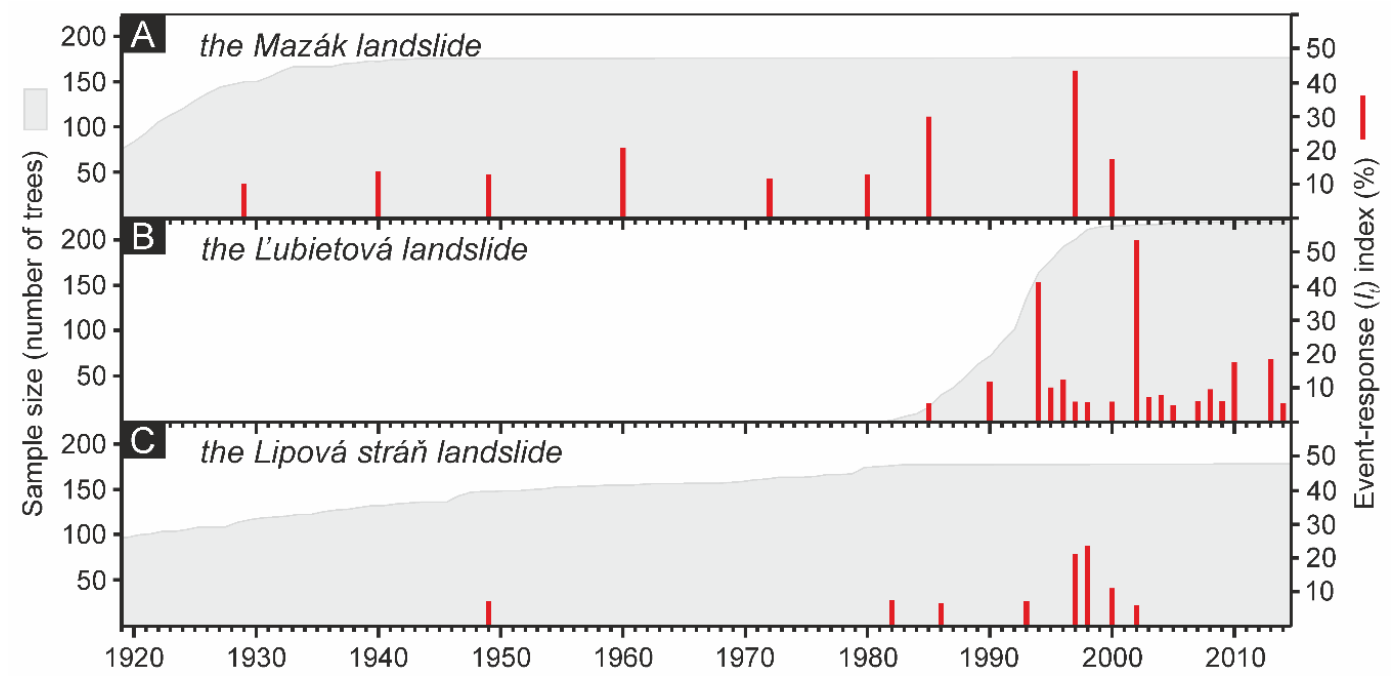

Figure 2. The chronology of dated mass movement events from all studied landslides expressed in terms of the standard event-response $\left(I_{t}\right)$ index ((A)—chronology of the Mazák landslide, $(\mathbf{B})$ —chronology of the L'ubietová landslide, (C)—chronology of the Lipová stráň landslide).

\subsection{Magnitude-Frequency Relationships of Mass Movement Events}

In total, nine mass movement events were dated on the Mazák landslide. Thus, the mean recurrence interval was 11.1 years. The frequencies of the events ranged between 0.01 (for the largest dated event) and 0.09 (for the smallest dated event) events. $\mathrm{yr}^{-1}$. The mean $I_{t}$ value of the dated events was $14.5 \%$. The maximum $I_{t}$ value was reconstructed for 1997 (44.0\%), and the minimum was obtained for $1929(10.0 \%)$. The $b$ coefficient for the M-F relationship using $I_{t}$ was 1.48 . The mean area affected by individual landslide reactivations (using the approach based on homogenous morphological units) was $16830 \mathrm{~m}^{2}$ (19.6\% of the total landslide afforested area). The maximum affected area was noted for $1997\left(24180 \mathrm{~m}^{2} ; 28.1 \%\right.$ of the area), and the minimum affected area was noted for $1929\left(8150 \mathrm{~m}^{2}\right.$; 9.5\%). The $b$ coefficient for the M-F relationship using the area based on morphological units was 1.84 . The mean affected area according to calculating the buffers around each tree was $2240 \mathrm{~m}^{2}(2.6 \%$ of the total landslide afforested area). The maximum affected area was noted for $1997\left(4540 \mathrm{~m}^{2} ; 5.3 \%\right)$, and the minimum was noted for $1929\left(920 \mathrm{~m}^{2} ; 1.1 \%\right)$. Expression of the Mazák landslide reactivation magnitude by various methods is visible in Figure 3. The $b$ coefficient for the M-F relationship using the area based on tree buffers was 1.44. The highest correlation between indicators of landslide magnitude was that between landslide magnitude expressed in terms of $I_{t}$ and the area based on tree buffers (0.92), and the lowest correlation was between $I_{t}$ and the area based on morphological units (0.74). The correlation between the area based on tree buffers and that based on morphological units was 0.85 . The M-F relationships for the Mazák landslide and the correlation relationships are visible in Figure 4.

Seventeen mass movement events with a mean recurrence interval of 0.5 years were dated on the L'ubietová landslide. The frequency of dated events ranged between 0.03 and 0.6 events.year ${ }^{-1}$. The mean $I_{t}$ value of the dated events was $13.3 \%$, with the maximum value being noted for $2002(53.7 \%)$ and the minimum value being noted for 2005 (5.0\%). The $b$ coefficient for the M-F relationship using $I_{t}$ was 1.14. The mean area affected by landslide reactivation during one landslide reactivation (based on the tree buffers) was $1910 \mathrm{~m}^{2}(0.98 \%$ of the total landslide afforested area). The largest area was affected in $2002\left(7800 \mathrm{~m}^{2} ; 3.99 \%\right)$ and the smallest in $1990\left(700 \mathrm{~m}^{2} ; 0.24 \%\right)$. Expression of the L'ubietová landslide reactivation magnitude by various methods is visible in Figure 5. The $b$ coefficient for the $\mathrm{M}-\mathrm{F}$ relationship using the area based on tree buffers was 1.12. The affected area based on homogenous morphological units was not calculated for this landslide, due to the flow-like character of its surface. The correlation between $I_{t}$ and the area based on tree buffers was 0.94 . The M-F relationships for the L'ubietová landslide and the correlation relationships are visible in Figure 6. 

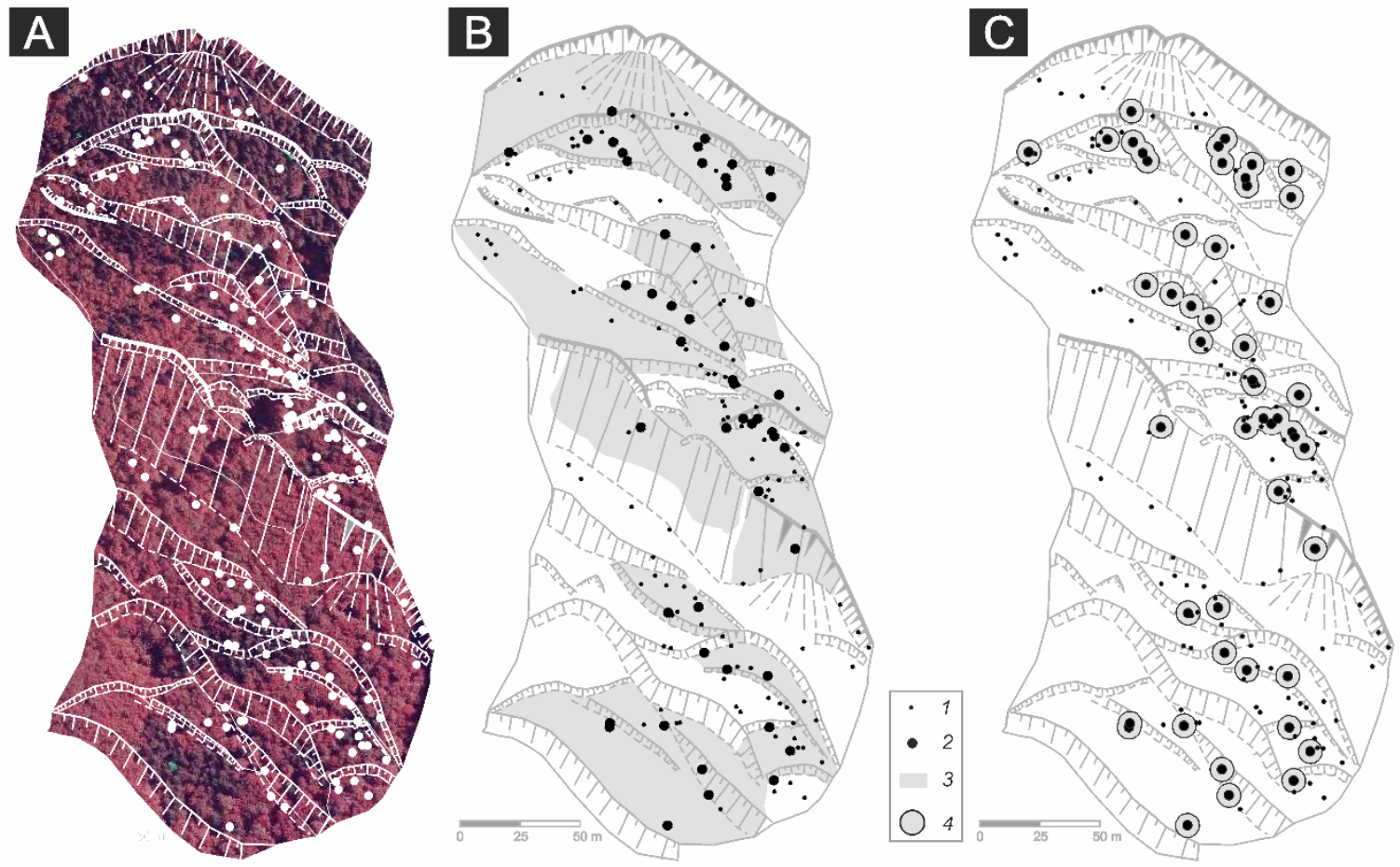

Figure 3. Afforestation of the Mazák landslide area (A) based on the infrared picture; and the area affected by landslide reactivation in a case year 1985 based on homogenous morphological units (B) and tree buffers (C) (1-position of sampled trees, 2-position of trees with landslide signal in particular year, 3-reactivated area during particular event, 4-tree buffer).
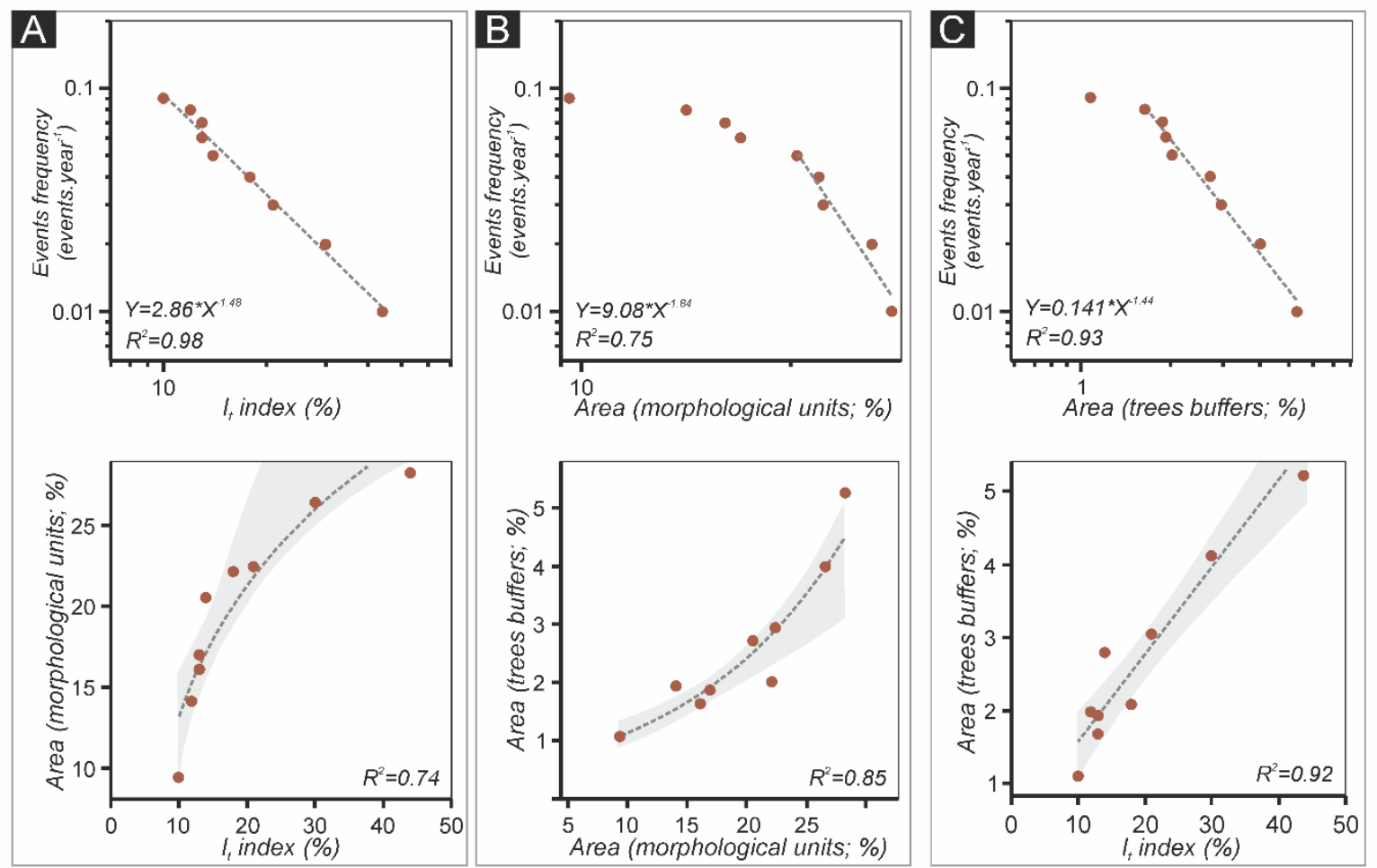

Figure 4. The magnitude-frequency relationships of the Mazák landslide, and the relationships among the methods of expressing magnitude ((A) —relationships for $I_{t}$ index, (B) -relationships for morphological units based area, (C)—relationships for trees buffers based area). 


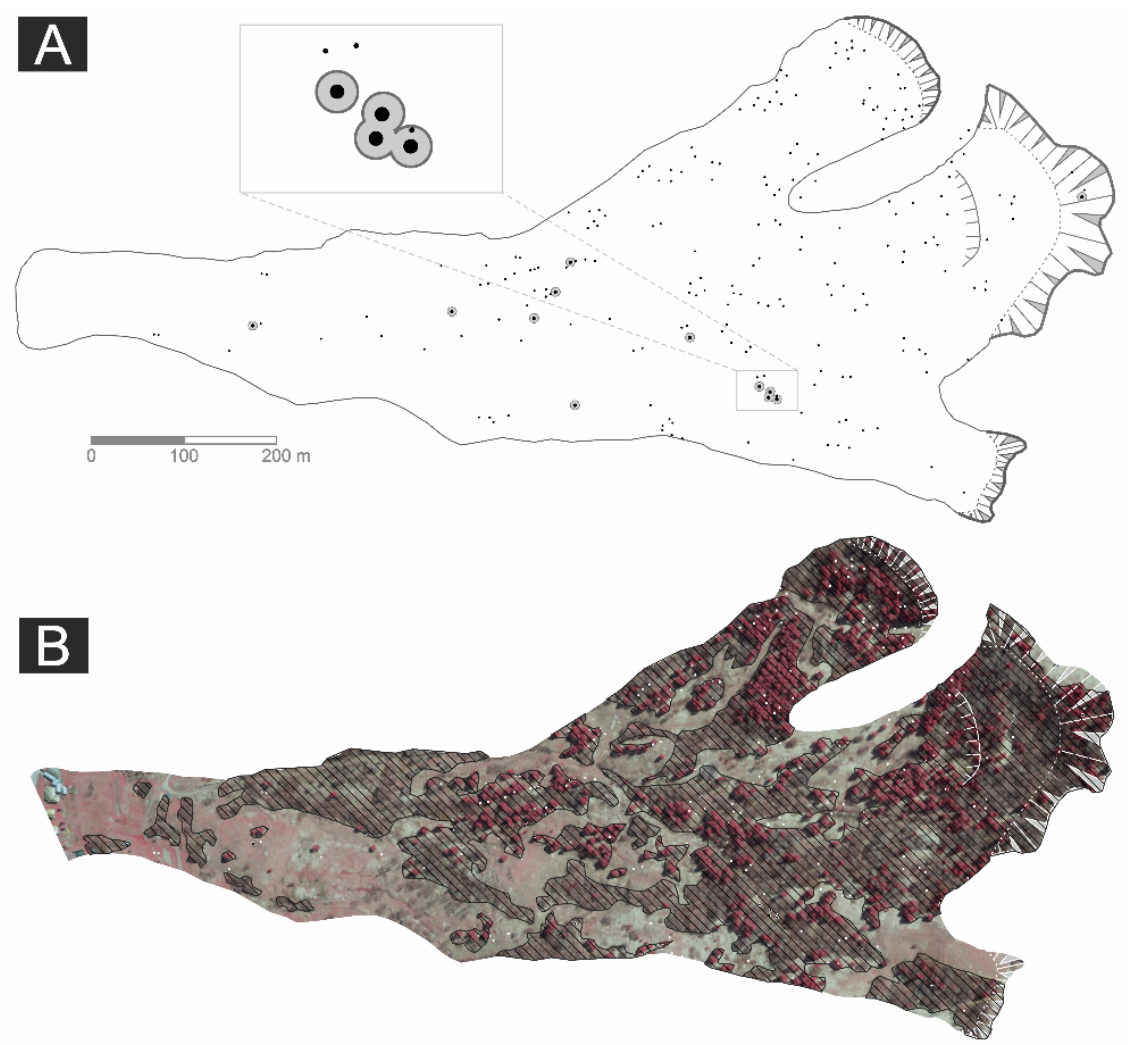

Figure 5. The area affected by landslide reactivation (A) in a case year 2005 based on tree buffers (the detail shows the overlap of buffers in the cluster of affected trees) and the afforestation of the L'ubietová landslide (B).
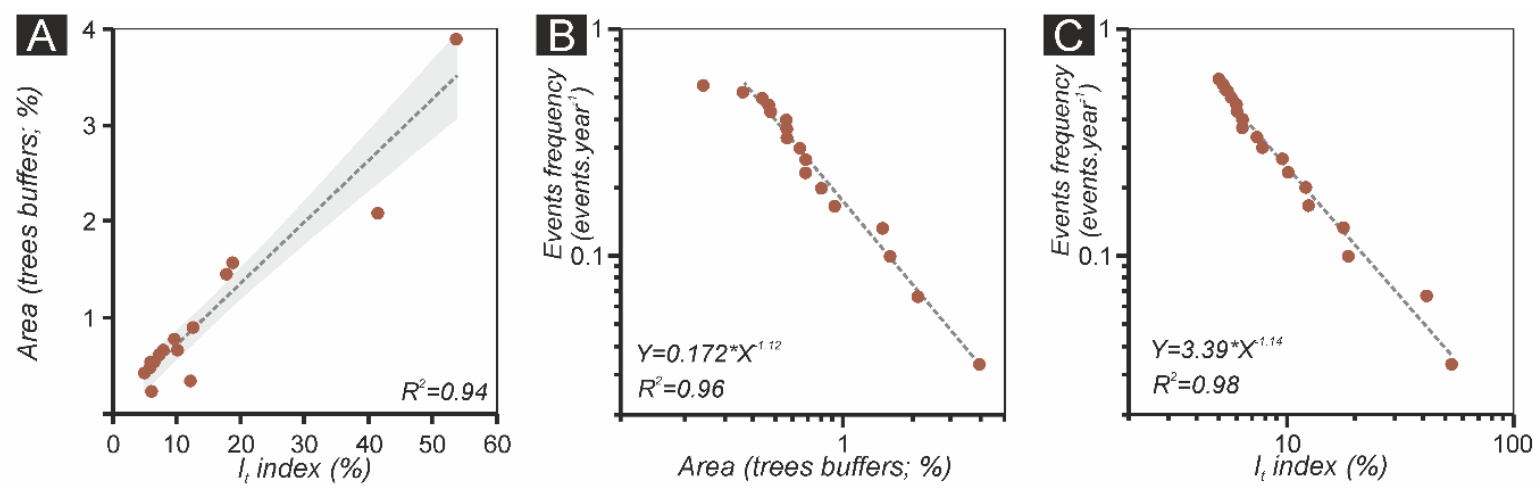

Figure 6. The magnitude-frequency relationships of the L'ubietová landslide, and the relationships among the methods of expressing magnitude ((A) - relationships for $I_{t}$ index and trees buffers, (B) - M-F for trees buffers based area, (C)-M-F for $I_{t}$ index).

Eight mass movement events with a mean recurrence interval of 8.1 years were dated on the Lipová strán landslide. The events' frequencies ranged between 0.007 and 0.06 events.yr ${ }^{-1}$. The mean $I_{t}$ value of the dated events was $11.6 \%$ (maximum $I_{t}=23.9$ in 1998; minimum $I_{t}=6.2 \%$ in 2002). The $b$ coefficient for the M-F relationship using $I_{t}$ was 1.27 . The mean area affected by landslide reactivations (based on morphological units) was $33,780 \mathrm{~m}^{2}$ ( $24.1 \%$ of the total landslide area). The maximum affected area was noted for $1998\left(53,210 \mathrm{~m}^{2} ; 37.9 \%\right)$, and the minimum area was noted for $1993\left(21,200 \mathrm{~m}^{2}\right.$; $15.1 \%)$. The $b$ coefficient for the M-F relationship using the area based on morphological units was 1.76. The mean affected area during landslide reactivation calculated based on the tree buffers was $1530 \mathrm{~m}^{2}$ (1.1\% of the total landslide area). The largest area was affected in $1998\left(3200 \mathrm{~m}^{2} ; 2.3 \%\right)$, and the smallest area was affected in $2002\left(750 \mathrm{~m}^{2} ; 0.7 \%\right)$. Expression of the Lipová stráň landslide reactivation 
magnitude by various methods is visible in the Figure 7. The $b$ coefficient for the M-F relationship using the area based on the tree buffers was 1.19. The highest correlation coefficient was calculated between $I_{t}$ and the area based on tree buffers (0.98) and the lowest correlation coefficient was calculated between $I_{t}$ and the area based on morphological units (0.87). The correlation between the area based on tree buffers and the area based on morphological units was 0.93 . The M-F relationships for the Lipová stráň landslide and the correlation relationships are visible in Figure 8.

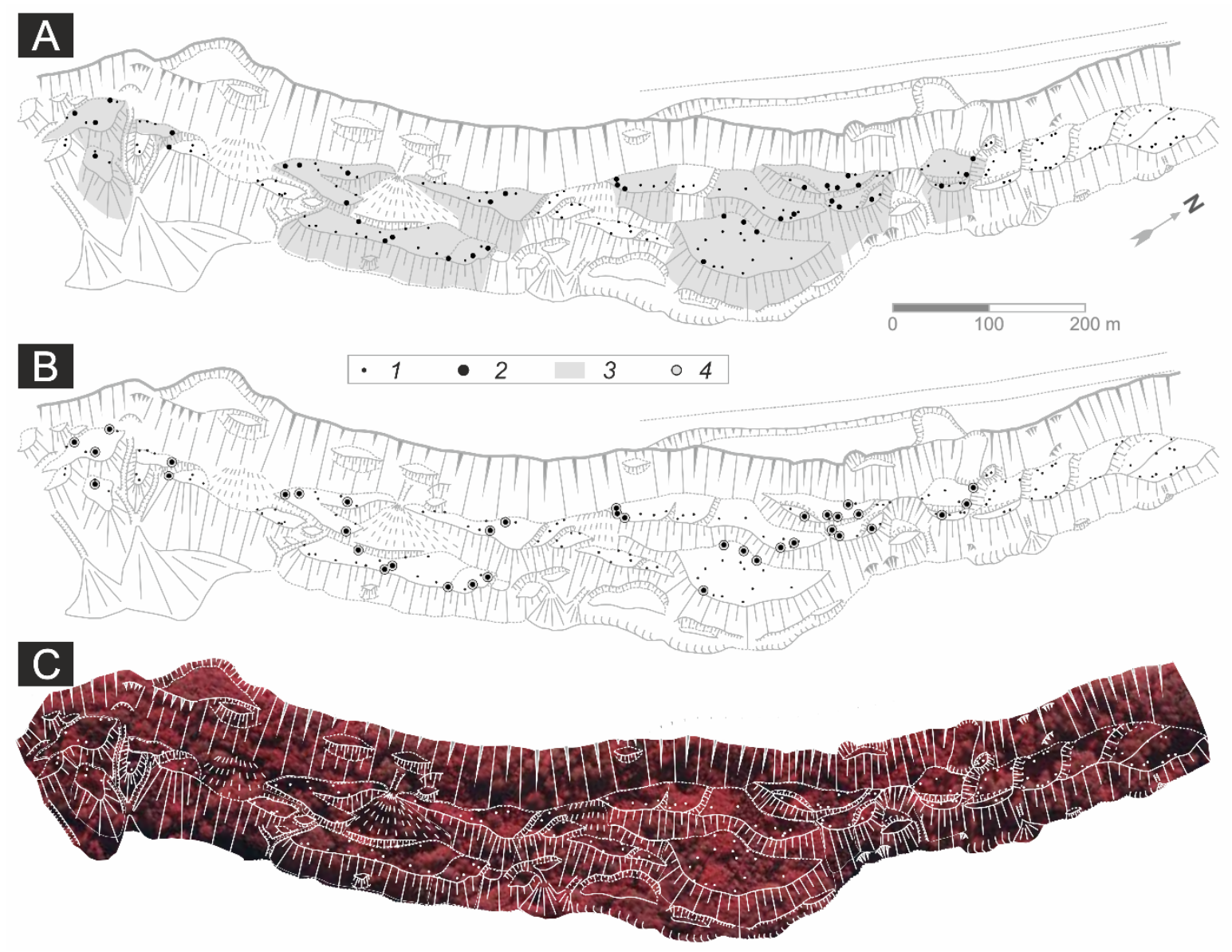

Figure 7. The area affected by landslide reactivation in a case year 1997 based on homogenous morphological units (A) and tree buffers (B), and the afforestation of the Lipová stráň landslide area (C) based on the infrared picture (1-position of sampled trees, 2-position of trees with landslide signal in a particular year, 3-reactivated area during a particular event, 4-tree buffer). 

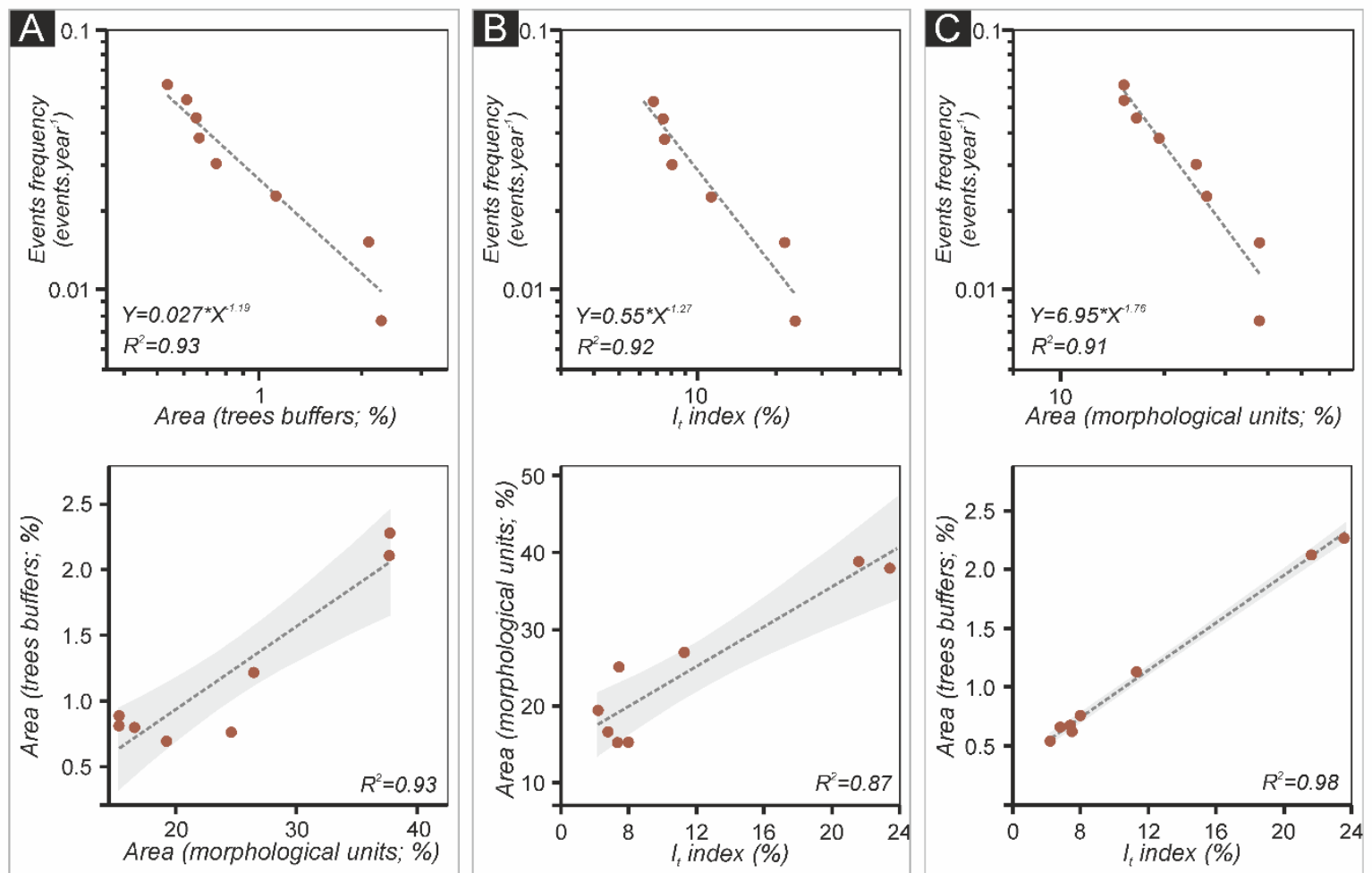

Figure 8. The magnitude-frequency relationships of the Lipová strán̆ landslide, and the relationships among the methods of expressing magnitude ((A)-relationships for trees buffers based area, (B)-relationships for $\mathrm{I}_{\mathrm{t}}$ index, (C) - relationships for morphological units based area).

\section{Discussion}

The reconstruction of magnitude-frequency relationships was realized using dendrogeomorphic approaches; 2288 tree ring series were obtained from 572 disturbed trees on three different landslides. The standard dendrogeomorphic analysis focused on the identification and dating of growth disturbances (i.e., reaction wood, abrupt growth suppression, and eccentric growth) induced by landslide movements, and 34 mass movement events were identified from 1350 growth disturbances. The frequency of the events was expressed as events. $\mathrm{yr}^{-1}$, and the magnitude of the events was expressed in terms of (i) the standard $I_{t}$ index, (ii) the percentage of reactivated afforested area based on homogenous morphological units, and (iii) as the percentage of reactivated afforested area based on tree buffers.

The use of tree ring-based methods for expressing M-F relationships is quite rare. Although the studies of [39-41] present this approach as usable for M-F reconstruction, some limitations remain. The main limitations are common to all tree ring-based studies. Trees do not appear on all landslides, and the trees that grow on some landslides are not suitable for dendrogeomorphic analysis (e.g., tropical trees without classical tree ring structures). Some landslides are not fully covered by trees. In such cases, historical orthophotos can help by providing complementary information on past landslide activity [36]. That is why the afforested area of landslides served as a weight in this study. Tree age is the next limiting factor. Coniferous trees generally reach greater ages in comparison with broad-leaved species; nevertheless, tree ring-based chronologies of landslide movements cover at most several hundred years [59-61]. The short lengths of mass movement chronologies can limit the discovery of long-term trends that are important for the reconstruction of M-F relationships. In this study, the lengths of the chronologies reached 33, 66 and 100 years. These lengths can be seen as limited; however, when compared with those of [10] (60 years) or [41] (62 years), they are sufficient. On the contrary, the chronology from the Mazák landslide (which has a length of 100 years) can be considered one of 
the longest that has been used to identify M-F relationships from landslides reconstructed using tree ring-based approaches.

A classical problem of tree ring-based chronologies is the potential overlapping of signals in the tree ring series from individual trees in the case of frequently occurring mass movement events. As standard growth disturbances induced by mass movements last more than one year (usually several years and up to several tens of years), the older growth responses can hide the younger ones. For this reason, dendrogeomorphic chronologies of landslides are usually considered to be only minimal [23]. The next possible limitation of the tree ring-based approach for landslide frequency assessment is the changing sensitivity of trees to mass movement events with increasing age and size [22]. This effect has already been discovered in the case of tree responses to rockfall [37] and debris flows [26], as well as earth slides $[46,62,63]$. The ability of trees to record mass movement events in their tree ring series usually decreases with age and stem size, due to decreasing stem elasticity and the general age-dependent trend toward decreasing tree ring widths [51]. From this reasons, some mass movement events may be undetectable in the ring series of old trees, and the resulting chronology must again be considered as only a minimum.

The results of this study confirm the general expectation that M-F relationships obey power laws [16]. Only in the case in which area is based on homogenous morphological units for the Mazák landslide is the relationship not consistent with a power law over its full length. This can be associated with the censoring effect, for example, as described by [13]. Nevertheless, some other uncertainty can influence the establishment of the power-law model when working with tree ring-based data. For example, the range of empirical data can be small (smaller than two orders) for dendrogeomorphically-analysed landslides, or the number of empirical tree-ring based data can be limited (maximal 17 empirical points for the L'ubietová landslide in this study). These potential limitations have to be taken into account during similar research.

The $b$ coefficients obtained from the regression, using all methods of expressing landslide magnitude (the $I_{t}$ index; the percentage of area based on morphological units; and the percentage of area based on tree buffers), generally reached higher values (1.12-1.84) in comparison with the results of [41] ( $b=0.9$ for complex slides). The $b$ values from this study are even higher in comparison with those produced by other landslide types, such as rockfall [2]. This difference can be associated with various mechanisms or processes [64]. The $b$ values in this study even differ among different slide types. The translational slide (Mazák) reached values of 1.44-1.84, the flow-like slide (L'ubietová) reached values of 1.12-1.14, and the rotational slide (Lipová stráň) reached values of 1.19-1.76. Moreover, each landslide was developed under different geological and structural conditions. Therefore, the differences mentioned above can be attributed to various geological factors as suggested by [2], but landslide mechanisms have to be considered as well.

The $b$ values differ not only among the different landslide types, but also depend on the methods used to express landslide magnitude $\left(I_{t}, 1.14-1.48\right.$; the percentage of area using morphological units, 1.76-1.84; area using tree buffers, 1.12-1.44). In general, all these approaches express very high degrees of correlation (particularly $I_{t}$ and the percentage of area based on tree buffers). Nevertheless, the differences in the ranges are quite small among individual approaches. Although the standard $I_{t}$ index was previously exclusively used just as quantitative indicator of landslide chronological occurrence, its use as an expression of landslide magnitude seems to be a possible variant, due to its high degree of correlation with approaches based on areal expression.

Nevertheless, a very important role is played by the spatial distribution of the sampled trees. Particularly dense clusters of trees can negatively influence the resulting magnitude as expressed using $I_{t}$. Usually, all trees growing on a particular block are influenced by mass movement events. A high number of trees growing on such blocks can overestimate the real landslide magnitude, because only spatially limited landslide areas can be reactivated. Thus, the $I_{t}$ value, as an expression of landslide magnitude, can be recommended in the case of spatially regular distributions of analysed trees. Similar conclusions and recommendations were described by [60] and [23] for the purposes of 
spatio-temporal reconstruction of past mass movement events. The negative effect of trees sampled in dense clusters partially eliminate the approach based on the determination of percentage of affected areas using tree buffers. The tree buffers mutually overlap in clusters and negatively weight the cumulative effect of neighbour trees. The question to address has to do with the buffer diameter. The mean corona width, which approximately represents the extent of the root plate, was used in this study; nevertheless, different approaches can be used (e.g., the minimum distance between one pair of trees, fixed diameters in regular steps: 5, 10, 15 ... metres, etc.). The testing of various diameters of tree buffers for the expression of landslide magnitude should be a focus of future studies. This approach seems to be the only possible way to quantify the area affected by landslide reactivation in the case of flow-like slides or earthflows, i.e., slope deformation with a specific morphology that limits the possibility of delineating partial homogenous morphological units usable in dendrogeomorphic analysis (e.g., individual isolated sliding blocks), at least approximately. The approach adopted from [41], which is based on the expression of landslide magnitude as a quantification of the affected area using homogenous morphological units (modified in this study as a percentage of afforested area), is well applicable for slope deformations for which the delineation of such units is possible (e.g., block-type slides). It is not applicable to landslides with smoothed flow-like characters of their morphology. This approach does not suffer disadvantages due to the spatial clustering of sampled trees. Nevertheless, the absence of usable trees on some morphological units can cause some reactivation events to be undiscoverable.

\section{Conclusions}

Dendrogeomorphic approaches are generally considered as a valuable tool for analysing various aspects of landslide behaviour. The aim of this study was to extend the range of analysed problems regarding $\mathrm{M}-\mathrm{F}$ reconstruction. In total, 572 disturbed trees (2288 tree ring series) were analysed from three different types of landslides (a translational slide, a flow-like slide, and a rotational slide) that occur under different geological conditions. The frequency of mass movement events in the M-F relationships was expressed as the number of mass movement events per year. Landslide magnitudes were expressed in three ways (the value of the standard $I_{t}$ index; the percentage of afforested area affected by the landslide based on homogenous morphological units and based on tree buffers). The results enabled the verification of the generally assumed power-law character of landslide $\mathrm{M}-\mathrm{F}$ relationships. Next, based on the results, it is quite possible to use the $I_{t}$ index as an indicator of landslide magnitude, as its values are highly correlated with indicators of magnitude that are based on the quantification of the affected area.

This study confirmed that dendrogeomorphic methods are valuable tools for reconstructing M-F relationships for landslides, but some limitations have to be taken into account. Apart from the standard limitations of tree ring-based analyses, such as limitations on tree age (and therefore chronology length), the overlapping of signals in tree ring series, and the age and size-dependent sensitivity of trees to landslide movements, some specific aspects associated with M-F reconstruction were discovered. The spatial distribution of the analysed trees seems to be the most important factor (partially in cases where $I_{t}$ is used). The calculation of affected areas based on tree buffers successfully eliminates this possible problem. The calculation of affected areas based on morphological units is a suitable approach for translational and rotational slides, but it is unsuitable for flow-like slides, due to their surface morphology. The next important factor is possibly the limited number and range of empirical data obtained from dendrogeomorphic analysis of landslides for evidencing the power-law relationship of $\mathrm{M}-\mathrm{F}$.

Subsequent studies should focus on increasing the robustness of tree ring-based methods for M-F relationship determination. This mainly implies testing different tree buffer diameters for optimal expression of the areas affected by landslide reactivation, developing optimal spatial tree sampling strategies, or developing measures for the elimination of the mentioned limitations (e.g., the changes in the ability of trees to record mass movement events with increasing age and size). 
Funding: This research was funded by Czech Science Foundation, grant number 19-01866S and University of Hradec Králové, grant number 2102/2020.

Acknowledgments: The language was reviewed by American Journal Experts.

Conflicts of Interest: The author declares no conflict of interest.

\section{References}

1. Rickenmann, D. Empirical relationships for debris flows. Nat. Hazards 1999, 19, 47-77. [CrossRef]

2. Hungr, O.; Evans, S.G.; Hazzard, J. Magnitude and frequency of rock falls and rock slides along the main transportation corridors of south-western British Columbia. Can. Geotech. J. 1999, 36, 224-238. [CrossRef]

3. Guzzetti, F.; Reichenbach, P.; Wieczorek, G.F. Rockfall hazard and risk assessment in the Yosemite Valley, California, USA. Nat. Hazards Earth Syst. Sci. 2003, 3, 491-503. [CrossRef]

4. Van Steijn, H. Debris-flow magnitude-frequency relationships for mountainous regions of Central and Northwest Europe. Geomorphology 1996, 15, 259-273. [CrossRef]

5. Jakob, M.; Bovis, M.; Oden, M. The significance of channel recharge rates for estimating debris-flow magnitude and frequency. Earth Surf. Process. Landf. 2005, 30, 755-766. [CrossRef]

6. Hungr, O.; McDougall, S.; Wise, M.; Cullen, M. Magnitude-frequency relationships of debris flows and debris avalanches in relation to slope relief. Geomorphology 2008, 96, 355-365. [CrossRef]

7. Mao, L.; Cavalli, M.; Comiti, F.; Marchi, L.; Lenzi, M.A.; Arattano, M. Sediment transfer processes in two Alpine catchments of contrasting morphological settings. J. Hydrol. 2009, 364, 88-98. [CrossRef]

8. Mediero, L.; Santillán, D.; Garrote, L.; Granados, A. Detection and attribution of trends in magnitude, frequency and timing of floods in Spain. J. Hydrology 2017, 517, 1072-1088. [CrossRef]

9. Zhang, Q.; Gu, X.; Singh, V.P.; Sun, P.; Chen, X.; Kong, D. Magnitude, frequency and timing of floods in the Tarim River basin, China: Changes, causes and implications. Glob. Planet. Chang. 2016, 139, 44-55. [CrossRef]

10. Hovius, N.; Stark, C.P.; Allen, P.A. Sediment flux from a mountain belt derived by landslide mapping. Geology 1997, 25, 231-234. [CrossRef]

11. Malamud, B.D.; Turcotte, D.L.; Guzzetti, F.; Reichenbach, P. Landslide inventories and their statistical properties. Earth Surf. Process. Landf. 2004, 29, 687-711. [CrossRef]

12. Van Den Eeckhaut, M.; Poesen, J.; Govers, G.; Verstraeten, G.; Demoulin, A. Characteristics of the size distribution of recent and historical landslides in a populated hilly region. Earth Planet. Sci. Let. 2007, 256, 588-603. [CrossRef]

13. Pelletier, J.D.; Malamud, B.D.; Blodgett, T.; Turcotte, D.L. Scale-invariance of soil moisture variability and its implications for the frequency-size distribution of landslides. Eng. Geol. 1997, 48, 255-268. [CrossRef]

14. Yanosky, T.M.; Jarrett, R.D. Dendrochronologic evidence for the frequency and magnitude of paleofloods. In: House, P.K.; Webb, R.H.; Baker, V.R.; Levish, D.R. (Eds) Ancient floods, modern hazards: Principles and Applications of Paleoflood Hydrology. Water Sci. Appl. 2002, 5, 77-89.

15. Guzzetti, F.; Malamud, B.D.; Turcotte, D.L.; Reichenbach, P. Power-lawcorrelations of landslide areas in central Italy. Earth Planet. Sci. Lett. 2002, 195, 169-183. [CrossRef]

16. Tanyas, H.; van Westen, C.J.; Allstadt, K.E.; Jibson, R.W. Factors controlling landslide frequency-area distribution. Earth Surf. Proc. Landforms 2019, 30, 900-917. [CrossRef]

17. Dai, F.C.; Lee, C.F. Frequency-volume relation and prediction of rainfall induced landslides. Eng. Geol. 2001, 59, 253-266. [CrossRef]

18. Lang, A.; Moya, J.; Corominas, J.; Schrott, L.; Dikau, R. Classic and new dating methods for assessing the temporal occurrence of mass movements. Geomorphology 1999, 30, 33-52. [CrossRef]

19. Raška, P.; Klimeš, J.; Dubišar, J. Using local archive sources to reconstruct historical landslide occurrence in selected urban regions of the Czech Republic: Examples from regions with different historical development. Land Degrad. Dev. 2015, 2, 142-157. [CrossRef]

20. Pánek, T. Recent progress in landslide dating: A global overview. Progress Phys. Geogr. 2015, 39, $168-198$. [CrossRef]

21. Alestalo, J. Dendrochronological interpretation of geomorphic processes. Fennia 1971, 105, 1-139.

22. Stoffel, M.; Butler, D.R.; Corona, C. Mass movements and tree rings: A guide to dendrogeomorphic field sampling and dating. Geomorphology 2013, 200, 106-120. [CrossRef] 
23. Corona, C.; Lopez-Saez, J.; Stoffel, M. Defining optimal sample size, sampling design and thresholds for dendrogeomophic landslide sampling. Quat. Geochronol. 2014, 22, 72-84. [CrossRef]

24. Strunk, H. Dating of geomorphological processes using dendrogeomorphological methods. Catena 1997, 31, 137-151. [CrossRef]

25. Stoffel, M.; Bollschweiler, M. Tree-ring reconstruction of past debris flows based on a small number of samples-possibilities and limitations. Landslides 2009, 6, 225-230. [CrossRef]

26. Šilhán, K.; Pánek, T.; Hradecký, J.; Stoffel, M. Tree-age control on reconstructed debris-flow frequencies: Examples from a regional dendrogeomorphic reconstruction in the Crimean Mountains. Earth Surf. Process. Landf. 2015, 40, 243-251. [CrossRef]

27. Corona, C.; Rovéra, G.; Lopez-Saez, J.; Stoffel, M.; Perfettini, P. Spatio-temporal reconstruction of snow avalanche activity using tree rings: Jean Jeanne avalanche talus, Massif de l'Oisans, France. Catena 2010, 83, 107-118.

28. Voiculescu, M.; Onaca, A. Snow avalanche assessment in the Sinaia ski area (Bucegi Mountains, Southern Carpathians) using the dendrogeomorphology method. Area 2013, 45, 109-122. [CrossRef]

29. Stoffel, M.; Schneuwly, D.; Bollschweiler, M.; Lièvre, I.; Delaloye, R.; Myint, M.; Monbaron, M. Analyzing rockfall activity (1600-2002) in a protection forest-a case study using dendrogeomorphology. Geomorphology 2005, 68, 224-241. [CrossRef]

30. Šilhán, K.; Pánek, T.; Hradecký, J. Implications of spatial distribution of rockfall reconstructed by dendrogeomorphological methods. Nat. Hazards Earth Syst. Sci. 2013, 13, 1817-1826. [CrossRef]

31. Trappmann, D.; Corona, C.; Stoffel, M. Rolling stones and tree rings: A state of research on dendrogeomorphic reconstructions of rockfall. Prog. Phys. Geogr. 2013, 37, 701-716. [CrossRef]

32. Ruiz-Villanueva, V.; Diez-Herrero, A.; Stoffel, M.; Bollschweiler, M.; Bodoque, J.M.; Ballesteros, J.A. Dendrogeomorphic analysis of flash floods in a small ungauged mountain catchment (Central Spain). Geomorphology 2010, 118, 383-392. [CrossRef]

33. Ballesteros-Cánovas, J.A.; Czajka, B.; Janecka, K.; Lempa, M.; Kaczka, R.J.; Stoffel, M. Flash floods in Tatra Mountain streams: Frequency and triggers. Sci. Tot. Environ. 2015, 511, 639-648. [CrossRef] [PubMed]

34. Šilhán, K. Frequency, predisposition and triggers of floods in Flysch Carpathians: Regional study using dendrogeomorphic methods. Geomorphology 2015, 234, 243-253. [CrossRef]

35. Fantucci, R.; Sorriso-Valvo, M. Dendrogeomorphological analysis of a slope near Lago, Calabria (Italy). Geomorphology 1999, 30, 165-174. [CrossRef]

36. Lopez-Saez, J.; Corona, C.; Stoffel, M.; Astrade, L.; Berger, F.; Malet, J.P. Dendrogeomorphic reconstruction of past landslide reactivation with seasonal precision: Bois Noir landslide, southern French Alps. Landslides 2012, 9, 189-203. [CrossRef]

37. Šilhán, K.; Pánek, T.; Dušek, R.; Havlů, D.; Brázdil, R.; Kašičková, L.; Hradecký, J. The dating of bedrock landslide reactivations using dendrogeomorphic techniques: The Mazák landslide, Outer Western Carpathians (Czech Republic). Catena 2013, 104, 1-13. [CrossRef]

38. Moya, J.; Corominas, J. Determination of the spatial and temporal activity of landslides based on tree-ring analysis. In Proceedings of the Seventh International Symposium of Landslides, Balkema, Rotterdam, 17-21 June 1996; pp. 321-326.

39. Stoffel, M. Magnitude-frequency relationships of debris flows-a case study based on field surveys and tree-ring records. Geomorphology 2010, 116, 67-76. [CrossRef]

40. Jakob, M.; Friele, P. Frequency and magnitude of debris flows on Cheekye River, British Columbia. Geomorphology 2010, 114, 382-395. [CrossRef]

41. Corominas, J.; Moya, J. Contribution of dendrochronology to the determination of magnitude-frequency relationships for landslides. Geomorphology 2010, 124, 137-149. [CrossRef]

42. Stefanini, M.C. Spatio-temporal analysis of a complex landslide in the Northern Apennines (Italy) by means of dendrochronology. Geomorphology 2004, 63, 191-202. [CrossRef]

43. Šilhán, K. Dendrogeomorphological analysis of the evolution of slope processes on flysch rocks (Vsetínské vrchy Mts; Czech Republic). Carpath. J. Earth Environ. Sci. 2012, 7, 39-49.

44. Wistuba, M.; Malik, I.; Wójcicki, K.; Michałowicz, P. Coupling between landslides and eroding stream channels reconstructed from spruce tree rings (examples from the Carpathians and Sudetes-Central Europe). Earth Surf. Process. Landf. 2015, 40, 293-312. [CrossRef]

45. Šilhán, K. Can tree tilting indicate mechanisms of slope movement? Eng. Geol. 2015, 199, 157-164. [CrossRef] 
46. Šilhán, K. How different are the results acquired from mathematical and subjective methods in dendrogeomorphology? Insights from landslide movements. Geomorphology 2016, 253, 189-198. [CrossRef]

47. Prokešová, R.; Kardoš, M.; Tábořík, P.; Medved'ová, A.; Stacke, V.; Chudý, F. Kinematic behaviour of a large earthflow defined by surface displacement monitoring, DEM differencing, and ERT imaging. Geomorphology 2014, 224, 86-101. [CrossRef]

48. Šilhán, K.; Prokešová, R.; Medved'ová, A.; Tichavský, R. The effectiveness of dendrogeomorphic methods for reconstruction of past spatio-temporal landslide behaviour. Catena 2016, 147, 325-333. [CrossRef]

49. Čech, S. Geological map 1:50 000 Rychnov nad Kněžnou; Czech Geological Survey: Brno, Czechia, 2001.

50. Fussgänger, F.; Jadroň, D.; Banský, M.; Tyleček, B. L'ubietová-Translational Slide, Final Report from Geological Surveying; Geofond: Bratislava, Slovakia, 1978; p. 78. (In Slovak)

51. Stoffel, M.; Bollschweiler, M. Tree-ring analysis in natural hazards research-an overview. Nat. Hazards Earth Syst. Sci. 2008, 8, 187-202. [CrossRef]

52. VIAS Vienna Institute of Archaeological Science, Time Table. Installation and Instruction Manual, Ver. 2.1; VIAS: Wien, Austria, 2005.

53. Westing, A.H. Formation and function of compression wood in gymnosperms II. Bot. Rev. 1965, 34, 51-78. [CrossRef]

54. Carrara, P.; O'Neill, J.M. Tree-ring dated landslide movements and their relationship to seismic events in southwestern Montana, USA. Quat. Res. 2003, 59, 25-35. [CrossRef]

55. Braam, R.R.; Weiss, E.E.J.; Burrough, P.A. Spatial and temporal analysis of mass movement using dendrochronology. Catena 1987, 14, 573-584. [CrossRef]

56. Shroder, J.F. Dendrogeomorphological analysis of mass movement on Table Cliffs Plateau, Utah. Quat. Res. 1978, 9, 168-185. [CrossRef]

57. Reardon, B.A.; Pederson, G.T.; Caruso, C.J.; Fagre, D.B. Spatial reconstructions and comparisons of historic snow avalanche frequency and extent using tree rings in Glacier National Park, Montana, U.S.A. Arct. Antarct. Alp. Res. 2008, 40, 148-160. [CrossRef]

58. ESRI. ArcGIS 10.1; ESRI: Redlands, CA, USA, 2011.

59. Šilhán, K.; Pánek, T.; Hradecký, J. Tree-ring analysis in the reconstruction of slope instabilities associated with earthquakes and precipitation (the Crimean Mountains, Ukraine). Geomorphology 2012, 173-174, 174-184. [CrossRef]

60. Lopez-Saez, J.; Corona, C.; Stoffel, M.; Schoeneich, P.; Berger, F. Probability maps of landslide reactivation derived from tree-ring records: Pra Bellon landslide, southern French Alps. Geomorphology 2012, 138, 189-202. [CrossRef]

61. Zhang, Y.; Stoffel, M.; Liang, E.; Guillet, S.; Shao, X. Centennial-scale process activity in a complex landslide body in the Qilian Mountains, northeast Tibetan Plateau, China. Catena 2019, 179, 29-38. [CrossRef]

62. Šilhán, K. Tree ring eccentricity in the dendrogeomorphic analysis of landslides-A comparative study. Catena 2019, 174, 1-10. [CrossRef]

63. Šilhán, K.; Stoffel, M. Impacts of age-dependent tree sensitivity and dating approaches on dendrogeomorphic time series of landslides. Geomorphology 2015, 236, 34-43. [CrossRef]

64. Brunetti, M.T.; Guzzetti, F.; Rossi, M. Probability distributions of landslide volumes. Nonlinear Process. Geophys. 2009, 16, 179-188.

(C) 2020 by the author. Licensee MDPI, Basel, Switzerland. This article is an open access article distributed under the terms and conditions of the Creative Commons Attribution (CC BY) license (http://creativecommons.org/licenses/by/4.0/). 